\title{
A NOTE ON THE INFLUENCE OF THE CIRCULATION ON THE UTILIZATION OF CARBOHYDRATES ${ }^{1}$
}

By RALPH PEMBERTON AND F. A. CAJORI

(From the Laboratory of Clinical Chemistry, Presbyterian Hosbital. Philadelphia)

(Received for publication December 1, 1927)

In a recent paper published in this JouRNAL, Lennox and Bellinger (1) have presented the results of an extensive study of the blood sugar curves of non-diabetic individuals, following the repeated oral and intravenous administration of glucose. They find that in the majority of their subjects the blood sugar curve was higher at the initial trial than it was 1 to 312 days later, after sugar administration had been repeated. In view of these findings Lennox suggests that he is "loathe to conclude that a lowered second curve is necessarily due to treatment or to experimental procedure." He suggests that the lowering of the height of the second curve is to be ascribed to the influence of the first ingestion of glucose.

Prominent among the work cited is that of Cajori, Crouter and Pemberton (2) on the effect of changes in the circulation on carbohydrate utilization. The purpose of the present communication is to show that Lennox's criticism of the interpretation of repeated blood sugar curves does not apply to the above mentioned work of the present writers.

Cajori, Crouter, and Pemberton (2) found that an exaggerated and prolonged hyperglycemia following the ingestion of glucose could be induced in a certain proportion of patients with chronic arthritis by interference with the blood supply to large muscle masses through elevation of the legs. The results of these experiments seemed of considerable significance in that they offered, with other evidence, an explanation of certain of the pathological changes in arthritis; and, of the delayed sugar removal from the blood ("lowered sugar tolerance")

1 The work here reported is part of a study on chronic arthritis in collaboration with R. B. Osgood, M.D., of Boston. The expenses were defrayed by contributions from various sources, including a number of patients. 
so frequently encountered in arthritis (3). These experiments also indicated that the character of the blood supply to tissues active in sugar removal is an important factor in the early utilization of carbohydrates. The importance of these conclusions was such that it seemed advisable to repeat the experiments and extend the series of cases studied. This was done and similar results were obtained; 50 per cent of those arthritics in whom a delayed sugar removal was not always present showed a higher blood sugar curve when the legs were elevated.

In the first series of these experiments, with one exception, the initial blood sugar curve was obtained when the subjects had their legs elevated, as Lennox has pointed out. According to him, the lower curve, subsequently found, may have been the result of a "natural" tendency, following glucose ingestion, for a second blood sugar curve to be lower than the first. In the second series, however (12 experiments) the first blood sugar curve, with two exceptions, was determined when the subject was seated; and the second when the legs were elevated. As has been mentioned above, results were obtained with essentially the same correlation between the position of the subject and height of blood sugar curve as in the first series, though the order of the experiment was reversed and the high blood sugar curve was observed on the second trial. This reversal of procedure in the two series was unpremeditated as we were at that time unfamiliar with Lennox's conclusions. We were interested in the response to the change in posture manifested by those arthritics ( 40 per cent) who ordinarily showed no delay in blood sugar removal; we endeavored to choose such types for the rather arduous experiment dealing with posture. We did not publish the details of this second series of experiments, contenting ourselves with the statement that the data were entirely confirmatory of the first series (4). These results now have added significance in that they are not open to the objections raised by Lennox in his recent article.

In 10 of the 12 experiments of the series here published, the first blood sugar curve was determined when the subject was seated; the. second curve was determined when the subject was recumbent with legs elevated. Five, or $\mathbf{5 0}$ per cent of the 10 subjects had a higher blood sugar curve when the legs were elevated. In our first series, 
TABLE 1

Effect of posture on the blood sugar curve following glucose ingestion

\begin{tabular}{|c|c|c|c|c|c|c|c|}
\hline \multirow{2}{*}{ Subject } & \multicolumn{3}{|c|}{ Seated } & \multicolumn{3}{|c|}{ Legs elevated } & \multirow{2}{*}{$\begin{array}{c}\text { Days } \\
\text { between } \\
\text { tests }\end{array}$} \\
\hline & Date & Time & $\begin{array}{l}\text { Blood } \\
\text { sugar }\end{array}$ & Date & Time & $\begin{array}{l}\text { Blood } \\
\text { sugar }\end{array}$ & \\
\hline & $1925-1926$ & minutes & $\begin{array}{l}\text { mgm. per } \\
100 \text { cc. }\end{array}$ & 1926 & minutes & $\begin{array}{l}\text { mgm. per } \\
100 \mathrm{cc} .\end{array}$ & \\
\hline 1 & December 31 & $\begin{array}{r}0 \\
30 \\
60\end{array}$ & $\begin{array}{r}94 \\
135 \\
92\end{array}$ & January 4 & $\begin{array}{r}0 \\
27 \\
60\end{array}$ & $\begin{array}{r}132 \\
99\end{array}$ & 4 \\
\hline 2 & January 5 & $\begin{array}{r}0 \\
32 \\
67\end{array}$ & $\begin{array}{r}90 \\
116 \\
130\end{array}$ & January 19 & $\begin{array}{r}0 \\
35 \\
65\end{array}$ & $\begin{array}{l}108 \\
155\end{array}$ & 14 \\
\hline 3 & January 13 & $\begin{array}{r}0 \\
30 \\
60\end{array}$ & $\begin{array}{l}103 \\
132 \\
115\end{array}$ & January 15 & $\begin{array}{r}0 \\
33 \\
65\end{array}$ & $\begin{array}{l}135 \\
127\end{array}$ & 2 \\
\hline 4 & January 18 & $\begin{array}{r}0 \\
40 \\
65\end{array}$ & $\begin{array}{r}99 \\
122 \\
128\end{array}$ & January 22 & $\begin{array}{r}0 \\
32 \\
60\end{array}$ & $\begin{array}{l}118 \\
110\end{array}$ & 4 \\
\hline 5 & January 22 & $\begin{array}{r}0 \\
35 \\
65\end{array}$ & $\begin{array}{l}166 \\
140\end{array}$ & $\begin{array}{c}\text { January } 20 \\
.\end{array}$ & $\begin{array}{r}0 \\
30 \\
60\end{array}$ & $\begin{array}{l}123 \\
174\end{array}$ & 2 \\
\hline 6 & February 1 & $\begin{array}{r}0 \\
40 \\
70\end{array}$ & $\begin{array}{l}104 \\
125 \\
111\end{array}$ & February 3 & $\begin{array}{r}0 \\
30 \\
60\end{array}$ & $\begin{array}{l}148 \\
167\end{array}$ & 2 \\
\hline 7 & February 15 & $\begin{array}{r}0 \\
30 \\
65\end{array}$ & $\begin{array}{l}104 \\
152 \\
120\end{array}$ & February 17 & $\begin{array}{r}0 \\
30 \\
60\end{array}$ & $\begin{array}{l}168 \\
146\end{array}$ & 2 \\
\hline 8 & March 3 & $\begin{array}{r}0 \\
30 \\
60\end{array}$ & $\begin{array}{r}99 \\
124 \\
109\end{array}$ & March 10 & $\begin{array}{r}0 \\
30 \\
60\end{array}$ & $\begin{array}{l}159 \\
121\end{array}$ & 7 \\
\hline 9 & March 10 & $\begin{array}{r}0 \\
30 \\
65\end{array}$ & $\begin{array}{r}99 \\
142 \\
122\end{array}$ & March 18 & $\begin{array}{r}0 \\
30 \\
60\end{array}$ & $\begin{array}{l}152 \\
146\end{array}$ & 8 \\
\hline $10^{*}$ & March 19 & $\begin{array}{r}0 \\
30 \\
60\end{array}$ & $\begin{array}{r}97 \\
151 \\
119\end{array}$ & March 25 & $\begin{array}{r}0 \\
40 \\
70\end{array}$ & $\begin{array}{l}129 \\
110\end{array}$ & 6 \\
\hline 11 & March 29 & $\begin{array}{r}0 \\
30 \\
60\end{array}$ & $\begin{array}{r}94 \\
156 \\
112\end{array}$ & April 2 & $\begin{array}{r}0 \\
35 \\
65\end{array}$ & $\begin{array}{l}153 \\
118\end{array}$ & 4 \\
\hline $12^{*}$ & April 24 & $\begin{array}{r}0 \\
30 \\
60\end{array}$ & $\begin{array}{l}157 \\
175\end{array}$ & April 17 & $\begin{array}{r}0 \\
30 \\
62\end{array}$ & $\begin{array}{r}98 \\
177 \\
189\end{array}$ & 7 \\
\hline
\end{tabular}

* Normal individual. 
previously published, the first curve was determined, in 12 of the 13 experiments, with the subject's legs elevated and the second curve was determined with the subjects seated. Seven, or 58 per cent, of the 12 subjects showed a higher curve when the legs were elevated. The details of the second series are presented in table 1.

Lennox's suggestion that the lowered blood sugar curve, obtained when glucose is administered a second time results from the stimulating effect of the initial dose of glucose, is deserving of comment. Since the work of Foster (5), appreciation is general that glucose is a powerful stimulant to the sugar-disposing mechanism and that a much less pronounced hyperglycemia results from massive glucose ingestion if the mechanism which removes excess sugar from the blood has been previously stimulated by glucose administration. Reinhold and Karr (6) have shown that other sugars are effective, through previous feeding, in reducing the hyperglycemia resulting from glucose ingestion. Du Vigneard and Karr (7) and also Greenwald and his co-workers (8) have shown that proteins as well as carbohydrates stimulate the sugar-disposing mechanism, whereas following fat feeding an exaggerated hyperglycemia results after glucose administration; a situation which also prevails during fasting. How long the stimulating effect of glucose or other foods persists upon the mechanism that removes sugar from the blood has not been determined. The interval between successive tests in our two series varied, with two exceptions, from 2 to 14 days. In 6 of the 31 subjects of Lennox and Bellinger whose second blood sugar curve was lower than the initial curve, the interval between successive tests was similar to the interval in our experiments. In the others it was longer. In a number, the period between tests was 300 to 200 days (1, table 2, p. 335).

It does not seem probable that the stimulus of a dose of glucose should endure for 14 days, not to say many months, without being considerably modified, if not completely abolished, by the changing metabolic conditions incident to ordinary food ingestion.

The influence on the blood sugar curve of the state of nutrition (starvation; certain diets), together with the effect of previous food ingestion, has for some time been known. It would seem, nevertheless, that duplicate curves determined at intervals of a few days are 
TABLE 2

Blood sugar curves of arthritics, remaining persistently high

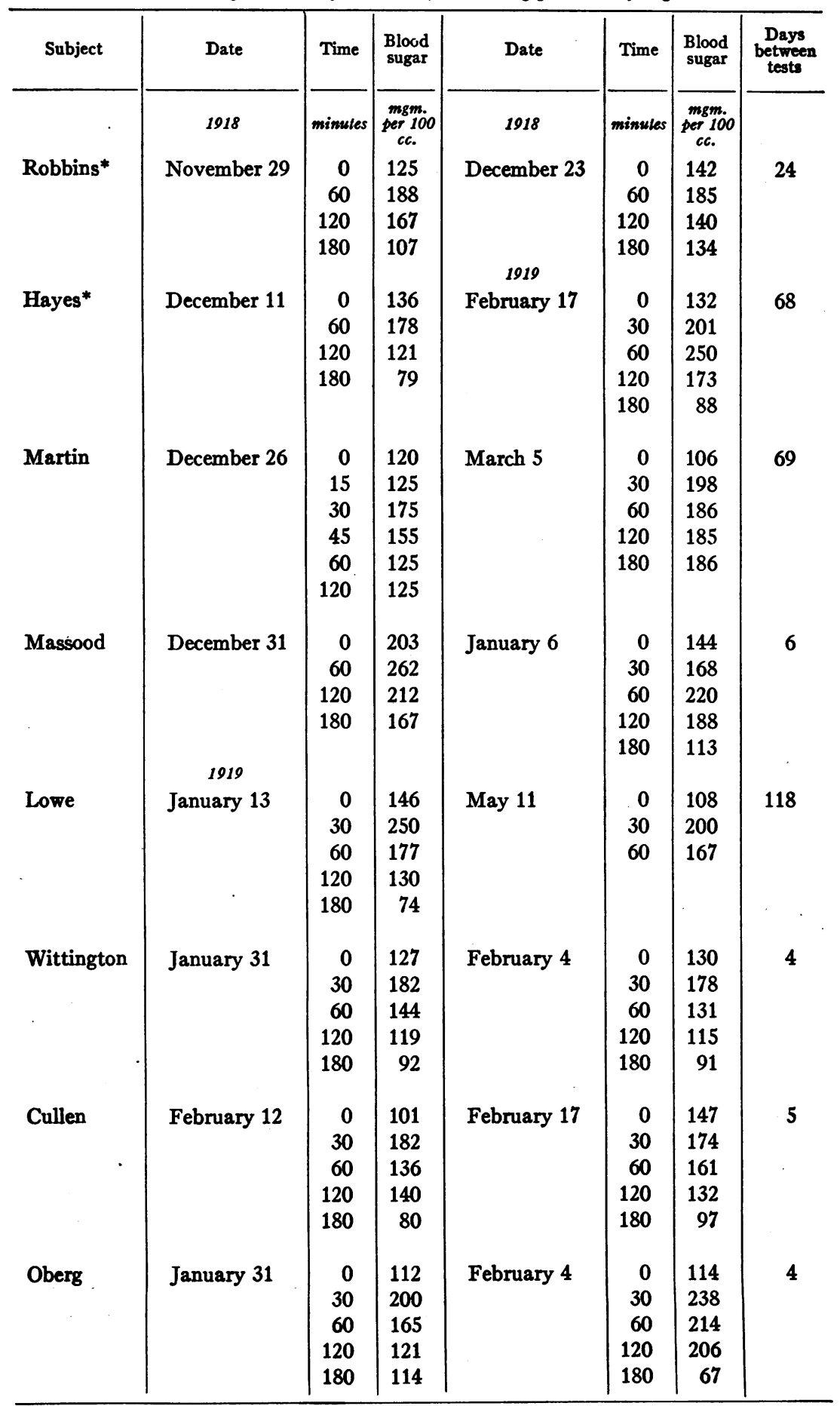

* Sugar determinations on plasma. 
indicative of conditions, experimental or otherwise that occur during the interval, affecting the ability of the body to remove from the blood excessive amounts of ingested glucose. At all events, any possible influence from a previous "sugar tolerance test" can be eliminated from discussion when considering the induction of a delayed sugar removal following interference with the circulation in the limbs. The experiments definitely indicate that a relative "anemia" of the muscular tissues at least constitutes a part of the pathological picture in arthritis and probably is one cause of the delayed sugar removal, of non-diabetic nature, seen in arthritis.

In this connection, attention should be called to that group of arthritics whose blood sugar curves remain persistently high. Lennox and Bellinger report similar findings in a minority of other types of subjects. Previous observations by Pemberton and Foster (9), published only in part, herewith recorded in table 2, show in a series of persons, some of whom were active arthritics, some convalescent and some symptomatically cured, that the second blood sugar curve was sometimes even higher than the first, notwithstanding previous ingestion of glucose at various intervals before the second test. Granting that the ingestion of sugar does influence subsequent carbohydrate utilization, it is plain that this influence may be greatly overshadowed by other factors and that, furthermore, in the cases cited, there is no evidence of any such influence from the previously injested glucose.

\section{BIBLIOGRAPHY}

1. Lennox, W. G., and Bellinger, M., J. Clin. Invest., 1927, iv, 331. Repeated Blood Sugar Curves in Non-diabetic Subjects.

2. Cajori, F. A., Crouter, C. Y., and Pemberton, R., J. Biol. Chem., 1925, lrvi, 89. The Effect of Changes in the Circulation on Carbohydrate Utilization.

3. Pemberton, R., Cajori, F. A., and Crouter, C. Y., J. A. M. A., 1925, lxxxv, 1793. Influence of Focal Infection and the Pathology of Arthritis. Results of Experiments.

4. Pemberton, R., Cajori, F. A., and Crouter, C. Y., J. A. M. A., 1926, lvxxuvii, 2148. The Influence of Focal Infection and the Pathology of Arthritis. Results of Experiments. Second Paper.

5. Foster, G. L., J. Biol. Chem., 1923, lv, 303. Studies on Carbohydrate Metabolism. II. An Interpretation of the Blood Sugar Phenomena following the Ingestion of Glucose. 
6. Reinhold, J. G., and Karr, W. G., J. Biol. Chem., 1927, lxxii, 345 . Carbohydrate Utilization. II. Rate of Disappearance of Various Carbohydrates from the Blood.

7. Du Vigneaud, V., and Karr, W. G., J. Biol. Chem., 1925, lxvi, 281. Carbohydrate Utilization. I. Rate of Disappearance of d-glucose from the Blood.

8. Greenwald, I., Gross, J., and Samet, J., J. Biol. Chem., 1924-25, 1xii, 401. The Nature of the Sugar in Normal Urine. II. The Sugar Excretion upon Various Diets and the Influence of Diet upon Glucose Tolerance with Some Remarks on the Nature of the Action of Insulin.

9. Pemberton, R., and Foster, G. L., Arch. Int. Med., 1920, xxv, 243. Studies of Arthritis in the Army Based on Four Hundred Cases. III. Studies on the Nitrogen, Urea, Carbon Dioxid Combining Power, Calcium, Total Fat and Cholesterol of the Fasting Blood, Renal Function, Blood Sugar and Sugar Tolerance. 